Лиляна М. Цонева

Великотырновский университет

Филологический факультет

Кафедра русистики

liliconeva@abv.bg
УДК 811.161 .1 '373

https://doi.org/10.18485/slavistika.2018.22.2.6

оригинални научни рад

примљено 28.02.2018.

прихваћено за штампу 04.10.2018.

\title{
ИМЯ ПОЛИТИКА КАК ЧАСТЬ ЕГО ОБРАЗА
}

В работе рассматриваются способы номинации политических субъектов в современных российских СМИ. Внимание уделяется средствам вторичной номинации (инициальным аббревиатурам, прозвищам, перифразам), направленным чаще всего на формирование негативной оценки образа политика в сознании адресата.

Ключевые слова: медиатекст, имя политика, средства номинации, инициальные аббревиатуры, прозвища, перифразы.

This paper examines the specifics of nomination of political subjects in contemporary Russian media. Special attention is paid to the means of secondary nomination (initials, nicknames, and paraphrases), which are most commonly intended to produce a negative assessment of the politician's image in the addressee's mind.

Keywords: media text, means of nomination, initials, nicknames, paraphrases.

В многочисленных научных работах, посвященных рассматриваемой теме, образ политика чаще всего понимается как социально-психологический феномен, включающий различные качества личности, которые проявляются в его работе и в меньшей степени в его частной жизни (хотя в наше время частная жизнь политиков не только активно обсуждается обществом, но нередко лежит в основе их образа). Как подчеркивает Е.Г. Беляевская, образ политического деятеля формируется на основании дискурса самого политика (его официальных и неофициальных выступлений), материалов СМИ, которые описывают деятельность политика, оценивают принимаемые им решения и обсуждают перспективы развития событий, а также биографических и политологических материалов, анализирующих деятельность политика (Беляевская 2012: 21).

Учитывая место и роль СМИ в современном обществе, можно утверждать, что именно материалы, публикуемые в СМИ, создают, моделируют образ политика. Хорошо известно, что СМИ в наше время являются основным инструментом, который не просто информирует, но и направляет восприятие и интерпретацию событий и субъектов, в том числе политических лидеров как основных действующих лиц на политической сцене. Поэтому образ политика корректнее определить как медиаобраз, “экранный образ», нередко довольно далекий от реального, что обусловлено рядом факторов и причин, которые требуют отдельного анализа.

Медиаобраз содержит невербальные и вербальные составляющие, направленные на формирование оценки образа политика в сознании адресата. В качестве субъекта оценки выступает автор медиатекста со своими идеологическими взглядами, креативными способностями и т. д. 
К невербальным средствам создания образа политика относятся фотографии, карикатуры, так называемые демотиваторы, различные средства параграфемики и т. д.

Языковые средства выражения оценки очень разнообразны, и к ним можно отнести обозначение определенных субъектов метафорами, оценочную лексику, фразеологизмы, формы языковой игры и т. д.

Важную роль в создании образа политиков играют и их имена, точнее - использование их имен в медиатексте. Имена политиков, как подчеркивают авторы исследования "Имя собственное в политике: язык власти и власть языка", - это важнейшие ориентационные знаки политического дискурса, знаки с необычайной информативной емкостью (Романов и др. 2000: 22).

В поисках ответа на интересный вопрос: «Каков же механизм действия имени собственного, который способен и возвышать его номинанта и, наоборот, делать его носителя совершенно никчемным человеком?», они отмечают следующее: «...имя собственное, вплетенное в прагматический контекст его использования, является своеобразным «сигналом личности» (термин Макса Люшера), способным формировать имидж носителя этого имени или номинанта как добрую, активную, симпатичную, бесконфликтную, деятельную личность. Точно так же оно способно участвовать в формировании прямо противоположного образа номинанта этого имени собственного» (Романов и др. 2000: 80).

Важно отметить, что употребление имен политиков имеет свою специфику, отличающую современные массмедиа от публицистики тоталитарного времени. Т.Р. Бочарова, говоря об иерархии служителей в советском обществе, подчеркивает, что «...политическое слово в советском политическом дискурсе функционировало не как средство коммуникации, а как часть ритуала, имело статус сакральности. Имена же политических “жрецов» и вовсе были неприкасаемыми» (Бочарова 1994: 24).

Сегодня многие политические реалии, в том числе политические субъекты, потеряли статус сакральных, более того, можно говорить о десакрализации этих субъектов и их имен. Это проявляется в том числе и в способах номинации политических и других важных субъектов.

Материалы российских СМИ позволяют прийти к выводу, что трехкомпонентная русская именная формула «имя + отчество + фамилия» (а также с инициалами), обязательная в публицистике времен тоталитаризма, сегодня встречается довольно редко. Например: А вот Михаил Сергеевич Горбачев не пытался осенью 1986 года играть роль «доброго копа» (Московский комсомолец 31.7.2017)

Об утрате отчества при именовании политиков говорится в работе О.А. Полюшкевич: «Мы вышли из поколения «Владимира Ильича» и «Леонида Ильича» и пришли к «Дмитрию Медведеву» и «Владимиру Путину» (Полюшкевич 2012: 84). По ее мнению, отказ от отчества, в том числе от отчества В. Путина, это переход к западным традициям общения, выбор новой политической ментальности, в корне отличающейся от советской и тем более от дореволюционной. Кроме того, это и знак «утраты энергетической, психологической, культурной поддержки со стороны предков, в виде упоминания имени отца» (Полюшкевич 2012: 86).

Славистика XXII/2 (2018) 
А.Д. Шмелев относит к изменениям в русском речевом этикете и «распространившийся обычай называть российских политических лидеров «на западный лад», при помощи имени в сочетании с фамилией (т. е. без отчества: Борис Ельцин, Анатолий Чубайс, Геннадий Зюганов)», объясняя его в первую очередь не западным влиянием, а тем, что газетная и телевизионная речь стали менее формальной (Шмелев 2005).

Наши наблюдения показывают, что самой частотной в современных СМИ является именно эта, сравнительно новая в русском официальном дискурсе формула - «имя + фамилия»: Министр обороны РФ, генерал армии Сергей Шойгу потребовал изменить порядок финансирования ремонта кораблей и подводных лодок. (Московский комсомолец 27.3.2013); Через европейские медиа на россиян транслируются позиции европейских элит, которые могут восхищаться или критиковать Владимира Путина или его конкурентов (Независимая газета 23.2.2018)

Редко встречается и формула «имя + отчество». Например: Но вот «борьбу с американским империализмом» летом 2017 года Владимир Владимирович ведет именно по методике Михаила Сергеевича (Московский комсомолец 31.7.2017)

Очень часто российские, а нередко и зарубежные политики, представлены только фамилией - самым информативным и самым «узнаваемым» компонентом именной формулы. К таким же выводам приходит О.А. Полюшкевич, которая отмечает, что контент-анализ российской прессы с 1984 по 2011 гг. на предмет упоминания имен политиков показал, что наиболее частое упоминание приходится на имя и фамилию, второе место занимает упоминание одной фамилии и третье место - полное упоминание фамилии, имени, отчества (Полюшкевич 2012: 86).

Номинация при помощи только фамилии господствует в последние годы в текстах разных жанров, причем не только в их важнейшем компоненте - заглавии (в котором, конечно, следует учитывать и жесткие требования объема), но и в самом тексте: В послании Путина заметили нарушение Конституичии (Московский комсомолец 27.2.2018); Сталинград для Путина является не только символом исторического успеха, но и моментом наивысшего драматизма человеческой истории. (Независимая газета 2.2.2018)

Использование только фамилии для номинации политиков, на наш взгляд, часто является не совсем корректным из-за наличия оттенка пренебрежения, неуважения, тем более по отношению к официальным политическим субъектам.

Оттенок пренебрежения, неуважения ослаблен в тех случаях, когда рядом с фамилиями, обычно в препозиции, даются апеллятивные идентификаторы (в другой терминологии - слова-сопроводители).

Невозможно не отметить разнообразие идентификаторов (чаще всего препозитивных), указывающих на должность, профессию, социальный статус и т. д., исключительно активных в российских печатных СМИ (о типах и функциях идентификаторов см.: (Васильева 2009: 34-77) Ср.: Президент Украины Петр Порошенко заявил о том, что считает российского лидера Владимира Путина более непредсказуемьм, чем 45-го главу Белого дома Дональда Tрампа. (Московский комсомолец 28.6.2017) 
Специального исследования заслуживают идентификаторы игрового характера, содержащие ироническую или негативную оценку субъекта, названного фамилией или двучленной формулой «имя + фамилия». Ср.: Не успев получить народного где-нибудь на Северном Кавказе и пост министра культуры где-нибудь в Заволжье или Приуралье, вольный борец с налогами франко-русский артист Депардье тихо и уютно обосновался в маленьком бельгийском городке Нешэн. (Итоги 25.3.2013); Лидером социально-политической устойчивости стала Мордовия, власти которой подарили новоиспеченному россиянину актеру Жерару Депардье квартиру. (КоммерсантЪ 4.2.2013)

Использование только личного имени (как правило, зарубежных политиков) встречается исключительно редко, особенно в аналитических и информационных медиатекстах. Ср., например, самостоятельное употребление имени Хиллари: Проблема в том, что Россия является «империей зла» в глазах не только Хиллари, но и многих республиканцев (Московский комсомолец 9.11.2016); Причина падения котировок Хиллари очевидна (Московский комсомолец 7.9.2016)

Редкие гипокористические формы используются, как правило, для подчеркивания иронически-снисходительного отношения к референту. Такими можно считать активные в современных СМИ формы Миша, Мишка, а также типичные для грузинского языка формы Мишико, Михо для номинации М. Саакашвили и прежде всего для подчеркивания его незрелости как политического субъекта, несамостоятельности его действий. Кстати, эти формы - только часть разнообразных средств для иронизации, дискредитации этого политика, любимой мишени современных российских СМИ. Например: Ведь оценка правления Мишико в Одессе началась уже на следующее утро после его назначения. Депутаты горсовета в первый же день назвали его Мишкойподкидышем (Комсомольская правда 6.9.2015)

Интерес представляют и вторичные средства номинации - инициалы, прозвища и перифразы, заменяющие реальные имена и формирующие, как правило, негативный образ референта.

Как отмечает В.Г. Кульпина, использование вторичных имен “возможно лишь в условиях культурной общности членов данного социума, которые совместно владеют определенным запасом знаний, представлений, ассоциаций, составляющих лексический фон данной словесной единицы» (Кульпина 2002:180).

Отсутствие таких знаний может привести, как известно, к коммуникативному провалу. Так, широко употребительные в недалеком прошлом прозвища Минеральный секретарь и Лимонадный Джо, которые М. Горбачев получил за антиалкогольную кампанию в 1985-86 гг., скорее всего, неизвестны многим современным людям. Об этом говорится в следующем примере: Впрочем, правды ради стоит отметить, что для большей части поколения второй половины 80-х Горбачев - просто картинка из учебника истории, и никаких личныхх чувств к «минеральному секретарю» тут уже и вовсе нет (Взгляд 3.3.2009)

К вторичным номинациям относятся инициальные аббревиатуры имени, отчества и фамилии. О.А. Давыдова, анализируя материалы СМИ конца XX в., определяет трехбуквенные аббревиатуры как новую форму именования поли-

Славистика XXII/2 (2018) 
тиков, еще не оформленную (с точками или без точек); по ее наблюдениям, чаще всего в то время использовались аббревиатуры ЧВС и БАБ (Давыдова 2001). В рассмотренном нами материале этот способ используется чаще все-

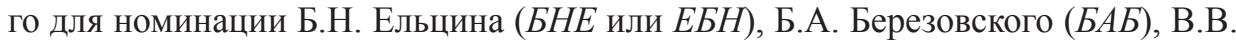
Путина (BВП), Д.А. Медведева (ДАМ), редко - для номинации других российских политических субъектов.

Активность подобных аббревиатур, скорее всего, можно объяснить и дополнительными оттенками в некоторых из них - например, паронимической близостью аббревиатуры ЕБН с нецензурным словом или возможностью двоякого понимания аббревиатуры ВВП (для называния В.В. Путина и как экономический термин).

Одно ярких из средств вторичной номинации - прозвища. Прозвище - «дополнительное неофициальное имя известного лица, данное в соответствии с характерной чертой или событием, узнаваемое членами социума и использующееся ими для именования» (Ненашева и др. 2016: 70). Чаще всего прозвища политиков и вообще известных людей непосредственно мотивированы поведением или особенностями речи референта, а также действиями и ситуациями, с которыми он связан.

Вполне справедливым можно считать сказанное о прозвищах Т.А. Ненашевой и Э.Н. Меркуловой: «Таким образом, сфера прозвищ становится широчайшим полем конструирования имиджа политика. Создание прозвищ, в основе которых лежат определенные, реальные или мнимые признаки, способствует закреплению в массовом сознании того или иного образа политика» (Ненашева и др. 2016: 78). Например, среди прозвищ болгарских политиков, как утверждает газета «Сега», можно найти всю флору и фауну (Тыква, Наричсс, Помидор, Картошка, Лягушка, Лошадь, Крокодил, Лисица, Обезьяна, Кобра, Бизон, Акула и т. п.). В то же время есть прозвища, которые можно отнести к «высокоинтеллектуальным и артистическим находкам» (Сега 25.2.2012)

Подобные «находки» есть и в рассматриваемом нами материале. К ним можно отнести, например, довольно экспрессивное прозвище Рекса Тиллерсона, госсекретаря США: В апреле Москву со своим первым визитом в качестве нового государственного секретаря США должен посетить Рекс Тиллерсон обладатель прозвища "Техасский тираннозавр Рекс», бывиий глава американских бойскаутов и политик (Московский комсомолец 21.3.2017) Основания для сравнения данного политика с самым известным хищным динозавром, Тираннозавром рекс (лат. Tyrannosaurus rex), на наш взгляд, можно связать с его именем Рекс, но и с его жестким характером.

Особенности внешности политических субъектов, хотя и реже, являются поводом для «награждения» прозвищем. Специального внимания в связи с этим заслуживает Д. Трамп, чья нестандартная внешность является предметом активного обсуждения и иронизирования в СМИ. Ср.: На пресс-конференичии 11 января в Нью-Йорке Дональд Трамп предстал в несколько новом имидже. Президент по кличке "Оранж»》, или по-нашему «Апельсин» из-за своего кислотного иввета волос с оранжевым отливом, появился с убеленными по возрасту платиновыми висками и успокоенной на несколько тонов макушкой (Новое время 12.01.2017) 
Именно прозвища «с намеком на волосы» - самые многочисленные среди разнообразных прозвищ, данных Д. Трампу в американских СМИ во время предвыборной кампании (Ненашева и др. 2016: 73).

Очень активны в современных СМИ и перифразы - описательные конструкции, заменяющие обозначенные сушествительным предметы, явления и т. д. Они выражают позитивную или негативную оценку называемого объекта и внушают определенные политические или социальные установки, поэтому являются важным средством манипуляции общественным сознанием.

Имена политиков - объект самого активного перифразирования. Перифразы, заменяющие имена политических субъектов, не просто называют лицо, а дают ему оценочную характеристику, подчеркивая важные его качества. Приведем пример с перифразой для обозначения В. Нуланд, госсекретаря США по делам Евразии: Строгая тетенька с печеньками отправилась в отставку, и ее бывшие подопечные тут же пошли в разнос (МК 1.2.2017)

Разумеется, для понимания и оценки экспрессивности перифразы адресат должен обладать определенными фоновыми знаниями о характерных чертах называемого субъекта, об его политической деятельности, о конкретных событиях с его участием и т. д. (в конкретном примере - это знания о В. Нуланд, которая принимала активное участие в событиях на Майдане в Киеве и даже раздавала людям печенье).

Экспрессивность перифразы может создаваться и за счет использования метафоры, метонимии и других средств образности. Обратим внимание на метафорическое употребление слов кукловод, король в перифразах, которыми обозначаются В. Сурков и П. Порошенко: И фон примечательный: уход «алавного кремлевского кукловода» так и не стал либеральным праздником (Огонек 13.5.2013); Порошенко и Тимошенко: конфетный король отказался от дуэли с «неистовой Юлей» (МК 19.5.2014)

Обобщая сказанное выше, отметим, что средства вторичной номинации активно используются для «навешивания ярлыков», или выражения негативной оценки политических субъектов. Их употребление можно определить как постоянную тенденцию, воплощающую стремление к экспрессивности, «зрелищности» выражения содержания в медиатексте.

\section{Цитирана литература}

Беляевская, Е. Г. «Фрейм «политик» в англоязычном биографическом дискурсе (к методике анализа)». Политическая лингвистика 40(2), 2012: 21-26.

Бочарова, Т. Р. «Имя политика как объект языковой игры». Политическое поведение и политические коммуникации: Психологические, социологические и филологические аспекты: тезисы и тексты докладов науч.-практ. конф. СПб., Красноярск, Иркутск, 1994, 24-26.

Васильева, Н. В. Собственное имя в мире текста. М.: URSS, 2009.

Давыдова, О. А. «Антропонимы на страницах современной публицистики», Справочно-информационный портал < http:/dic.gramota.ru/biblio/magazines/ gramota/kultura $>2.08 .2001$.

Славистика XXII/2 (2018) 
Кульпина, В. Г. «Психолингвистический анализ в реконструкции восприятия исторических личностей (имена, вторичные имена, прозвища Наполеона в России и Польше)». Мир психологии 3 (31), 2002: 176-191.

Ненашева, Т. А., Эдита Н. Меркулова. «К вопросу о роли прозвищной номинации в создании образа политика». Медиалингвистика 4 (14), 2016: 70-80.

Полюшкевич, О. А. «Имя нареченное в политическом дискурсе России». Аналитика культурологии 1 (22), 2012: 84-88.

Романов, А. А., Елена Г. Романова, Николай Ю. Воеводкин. Имя собственное в политике: язык власти и власть языка. Москва: Лилия ЛТД, 2000.

Цонева, Лиляна. Имена и люди. Ключевые имена в медиадискурсе. ВеликоТырново: ИВИС, 2017.

Шмелев, А. Д. «Ложная тревога или подлинная беда». Отечественные записки $2(22), 2005$.

Љиљана Цонева

ИМЕ ПОЛИТИЧАРА КАО САСТАВНИ ДЕО ЊЕГОВОГ ИМИЏА

Резиме

У раду се разматрају посебне карактеристике имена водећих политичара, која су одређена као кључна, у савременој руској штампи. Те особености, као и друге занимљиве карактеристике ових речи, сведоче о важној улози имена у стварању политичаревог имиџа. Анализа грађе је пружила основу за закључак да су савремени политичари, укључујући и руске, најчешће представљени формулом «име + презиме» или само презименом. Важна је и та чињеница да се у савременим медијским текстовима активно користе средства секундарне номинациије - иницијали, надимци и парафразе. Они су, по правилу, у служби формирања негативне слике политичара.

Кључне речи: име политичара, имиџ политичара, двокомпонентна формула, иницијалне абревијатуре, надимци, парафразе. 